\title{
Collection season and auxin treatment in the propagation by cuttings of mandarin hybrids ${ }^{1}$
}

\author{
Andrés Iván Prato Sarmiento ${ }^{2}$, Paulo Vitor Dutra de Souza ${ }^{3}$, Sergio Francisco Schwarz
}

\section{ABSTRACT}

Propagation by cuttings is an alternative for obtaining citrus rootstocks. The exogenous application of indolebutyric acid (IBA), cutting collection season and genotypes used may affect the rooting and vegetative growth of citrus rootstocks cuttings. Two experiments were conducted to study the influence of these factors. In the first one, semi-hardwood cuttings from the 'Sunki' mandarin hybrids $\mathrm{H} 49$ and $\mathrm{H} 77$ were collected in the fall and late spring of 2013 and treated with IBA $\left(0 \mathrm{mg} \mathrm{L}^{-1}, 1,500 \mathrm{mg} \mathrm{L}^{-1}\right.$ and 3,000 $\left.\mathrm{mg} \mathrm{L}^{-1}\right)$. For each collection season, a $2 \times 3$ (two genotypes $\times$ three IBA concentrations) factorial scheme was adopted, in a randomized blocks design. In the second experiment, the development of cuttings that rooted in the late spring was evaluated until grafting. In this case, a completely randomized experimental design was adopted, with the hybrids H49 and H77. The IBA treatments positively influenced rooting and number of roots only in the fall collection, peaking at $23.3 \%$ of rooted cuttings. In the late spring collection, rooting was close to $100 \%$, with the IBA treatment being unnecessary. Around $50 \%$ of cuttings from the 'Sunki' mandarin hybrids were ready for grafting at 14 months after cutting.

KEY-WORDS: Citrus spp.; plant growth regulator; vegetative propagation.

\section{INTRODUCTION}

Rootstock diversity is an important challenge in the Brazilian Citrus crop. Higher diversity is important to reduce the attack of plagues and events of abiotic stress. An extension of the genetic basis of the varieties used as rootstocks may contribute to reaching a higher yield and to the sustainability of the sector. However, there is still a wide genetic concentration in the use of rootstocks

\section{RESUMO}

Época de coleta e tratamento com auxina na propagação de híbridos de tangerineira por estaquia

A propagação por estaquia é uma alternativa para a obtenção de porta-enxertos de citros. A aplicação exógena de ácido indolbutírico (AIB), época de coleta das estacas e genótipos utilizados exercem efeito sobre o enraizamento e desenvolvimento de estacas de porta-enxertos de citros. Para estudar o efeito desses fatores, dois experimentos foram realizados. No primeiro, estacas semilenhosas dos híbridos de tangerineira 'Sunki' H49 e H77 foram coletadas no outono e final da primavera de 2013, sendo tratadas com AIB $\left(0 \mathrm{mg} \mathrm{L}^{-1}, 1.500 \mathrm{mg} \mathrm{L}^{-1} \mathrm{e}\right.$ $\left.3.000 \mathrm{mg} \mathrm{L}^{-1}\right)$. Em cada época de coleta, utilizou-se o esquema fatorial 2 x 3 (dois genótipos x três concentrações de AIB), sob delineamento em blocos casualizados. No segundo experimento, avaliou-se o desenvolvimento das estacas que enraizaram na primavera, até atingirem o ponto de enxertia. Neste caso, adotou-se o delineamento experimental inteiramente casualizado, com os híbridos H49 e H77. Os tratamentos com AIB influenciaram positivamente no enraizamento e número de raízes somente na coleta de outono, alcançando índice máximo de $23,3 \%$ de estacas enraizadas. Na coleta do final da primavera, o enraizamento ficou próximo a $100 \%$, sendo desnecessário o uso de AIB. Cerca de $50 \%$ das estacas dos híbridos de tangerineira 'Sunki' atingiram o ponto de enxertia 14 meses após a estaquia.

PALAVRAS-CHAVE: Citrus spp.; fitorregulador; propagação vegetativa.

in orchards, in which the 'Rangpur' lime (Citrus limonia Osb.) predominates. However, C. limonia is highly susceptible to the 'citrus sudden death' (Bassanezi et al. 2007, Pompeu Júnior \& Blumer 2011).

The success of the rootstock production phase depends, mostly, on its tendency to polyembryony, which facilitates the selection of nucellar embryos, thus maintaining the genetic uniformity and crop management (Rao et al. 2008).

1. Manuscript received in Mar./2016 and accepted for publication in Jun./2016 (http://dx.doi.org/10.1590/1983-40632016v4640211). 2. Corporación Colombiana de Investigación Agropecuaria (Corpoica C. I. La Suiza), Bucaramanga, Santander, Colombia. E-mail: aprato@corpoica.org.co.

3. Universidade Federal do Rio Grande do Sul, Faculdade de Agronomia, Departamento de Horticultura e Silvicultura, Porto Alegre, RS, Brazil,E-mails: pvdsouza@ufrgs.br, schwarz@ufrgs.br. 
The 'Sunki' mandarin (C. sunki Hort. ex. Tan.) has been recommended and used as rootstock in substitution of the 'Rangpur' lime, because of its tolerance to the 'citrus tristeza virus', 'citrus decline', 'citrus sudden death', salinity, drought and, additionally, because it provides a good productivity to the grafted cultivars (Siviero et al. 2003, Bassanezi et al. 2007). Nevertheless, the 'Sunki' mandarin has reduced the number of viable seeds per fruit (two to four), with low polyembryony $(<20 \%)$ and high frequency of zygotic embryos (Weiler et al. 2009, Santos et al. 2015). Therefore, it is important to study the feasibility of clonal propagation of 'Sunki' mandarin genotypes.

Among the 'Sunki' mandarin rootstock genotypes, there are the hybrids H49 and H77. These genotypes are offspring hybrids from the 'Sunki' mandarin as a male parent, originated in the breeding program of the Universidade Federal do Rio Grande do Sul, in the South of Brazil. These hybrids have great potential, since they are better than their parent ('Sunki' mandarin), in terms of number of seeds per fruit, number of embryos per seed and number of seedlings emerged from each seed (Weiler et al. 2009).

The cuttings propagation of citrus rootstock is an alternative method to reduce undesirable variability due to segregation and to allow a fast propagation of seedlings. This method has a potential use, following the current legislation on the production of citrus seedlings, where the mother plant maintenance and the seedlings production must be carried out in a protected environment (Souza \& Schäfer 2006). Despite this, the citrus species and genotypes show different responses to rooting. In addition, the cutting collection season, starch contents and use of growth regulators also affect the rooting ability (Andrade \& Martins 2003, Uzun \& Seday 2011, Oliveira et al. 2014).

This study aimed at evaluating the influence of indolebutyric acid and collection season on the rooting and vegetative growth of cuttings of two hybrid rootstocks of citrus derived from the 'Sunki' mandarin.

\section{MATERIAL AND METHODS}

The study was divided into two phases, performed from April 2013 to March 2015, at the Universidade Federal do Rio Grande do Sul
(UFRGS) (30 $\left.04^{\circ} \mathrm{S} ; 51^{\circ} 08^{\prime} \mathrm{W}\right)$, Rio Grande do Sul State, Brazil, where the climate, according to the Köppen classification, is Cfa, i.e., subtropical humid. The first phase evaluated the cuttings rooting ability and the second one studied the vegetative growth of the plants obtained in the previous phase.

The experiment was performed with branches (cuttings) collected from two 'Sunki' mandarin hybrids (H49 and H77). These hybrids come from a segregating population obtained through open pollination, in which the female parent is the 'Lee' tangelo [C. clementina Hort. ex. Tan. $\mathrm{x}$ (C. tangerina Hort. ex. Tan. x C. paradisi Macf.)] and the male parent is the 'Sunki' mandarin, identified by microsatellite molecular markers (Weiler et al. 2009). These plants (21 years old) were collected at the agronomic experimental station of the UFRGS ( $30^{\circ} 06$ 'S ; $51^{\circ} 39^{\prime} \mathrm{W}$ ), in Eldorado do Sul, Rio Grande do Sul State. All the crop management practices followed the recommendations for citrus (Koller 2009).

Initially, the hybrids H49 and H77 were collected in the fall (04/14/2013) and at the end of the spring (12/14/2013). From February to April 2013, before the fall cuttings collection, the accumulated precipitation in the experimental area was $285 \mathrm{~mm}$, with an average temperature of $22.9{ }^{\circ} \mathrm{C}$. From September to November 2013, before the spring cuttings collection, the precipitation was $557 \mathrm{~mm}$ and the average temperature was $19.8^{\circ} \mathrm{C}$.

Branches were selected from the apical portion of the canopy. Subsequently, semi-hardwood cuttings of 9-11 cm length, 0.2-0.4 cm diameter and with three mature leaves were prepared. The treatments consisted of two genotypes (hybrids H49 and H77) and three concentrations of indole-3-butyric acid (IBA) (absence, medium and high, with $0 \mathrm{mg} \mathrm{L}^{-1}$, $1,500 \mathrm{mg} \mathrm{L}^{-1}$ and 3,000 $\mathrm{mg} \mathrm{L}^{-1}$, respectively). For each collection season, a $2 \times 3$ (two genotypes $\mathrm{x}$ three IBA concentrations) factorial scheme was used, in a randomized blocks design, with three replications of 10 cuttings per plot. The IBA application was carried out through the immersion of the cuttings base in hydroalcoholic solution (a solvent made of $50 \%$ distilled water and $50 \%$ ethylic alcohol), up to $2 \mathrm{~cm}$, during $10 \mathrm{~s}$.

This experiment was performed in an intermittent mist chamber, on a masonry bench, covered with transparent plastic tiles $(75 \%$ light interception). The irrigation system was automatic 
and consisted of differentiated micro-sprinkling cycles: from 7 a.m. to 7 p.m., the duration of the cycle was $15 \mathrm{~s}$, performed every $2 \mathrm{~min}$; from $7 \mathrm{p} . \mathrm{m}$. to $7 \mathrm{a}$ a.m., the duration was $15 \mathrm{~s}$, every $14 \mathrm{~min}$ and $45 \mathrm{~s}$. The cutting stayed in plastic speedling trays of expanded polystyrene, with 72 cells filled with substrate of carbonized rice husk. This cutting lasted for 130 days in the collection of the fall season (average of $15.3 \pm 4.2^{\circ} \mathrm{C}$ and $92.6 \pm 5.4 \%$ relative humidity, in the intermittent mist chamber) and for 90 days in the collection at the end of the spring season (average of $26.8 \pm 5,3{ }^{\circ} \mathrm{C}$ and $86.8 \%$ relative humidity, in the intermittent mist chamber). The different time to evaluate each season was due to the accelerated rooting occurred in cuttings collected in the late spring, when compared to the late fall. At the end of those periods, the percentage of rooting (adventitious roots of at least $1 \mathrm{~mm}$ ), sprouting and number of adventitious roots per cutting were evaluated.

At the beginning and at the end of this phase, total reserves in the stems and leaves of the cuttings were determined separately, in the laboratory. For this, the vegetal material was dried $\left(65^{\circ} \mathrm{C}\right.$, to constant weight) and ground in a mill coupled with a sieve of 20 meshes per inch. One gram of each sample was sealed in nonwoven fabric for food filtering, and each sample was subjected to digestion (Priestley 1965). In the mother plants that provided cuttings, four replications per genotype (10/replication) were evaluated for total reserves, and, after the period in the intermittent mist chamber, there were four replications (10 cuttings/repetition) evaluated per treatment.

The data were submitted to analysis of variance and averages of significant factors were compared pairwise with $t$ tests. The significance levels were adjusted with Bonferroni correction. The statistical software SPSS $18.0^{\circledR}$ was used for these analyses. At the beginning, an individual statistical analysis for each cutting collection season (fall and end of spring) was performed, in which the homoscedasticity of both experiments (Levene's test) was verified. Subsequently, an analysis of variance was conducted, which involved the two cutting collection seasons, in order to observe the effect of interactions of the factors studied on the responses of the evaluated variances.

Since rooting was low in the cuttings collected in the fall, and there was not a significant IBA effect in the collection of the spring, an evaluation of the vegetative growth of the hybrids was performed only for the spring collection. In order to evaluate this, a randomized design with two treatments (hybrids H49 and H77) and three blocks was adopted, with each block formed by six cuttings of each hybrid that underwent the same IBA treatment.

For the second phase, the cuttings that rooted were transplanted individually into plastic bags of $4.5 \mathrm{~L}$, containing a substrate $\left(\mathrm{Vida}^{\circledR}\right.$, based on eucalyptus husk), and cultivated in galvanized aluminum, with a drip irrigation system, in a greenhouse, allowing the evaluation of their vegetative growth until grafting. Irrigation was applied using a dripping line with an exit for each cutting ( $0.6 \mathrm{~L} \mathrm{~h}^{-1}$ in-line dripper). The irrigation frequency consisted of three $(9$ a.m., 4 p.m. and 2 a.m.) daily four-min applications.

Cuttings were hedged in a single-stem system, with weekly removal of lateral sprouts. Fertilization consisted in the addition of a slow-release fertilizer (Osmocote $\left.{ }^{\circledR} 22-04-08\right)$ to the substrate, in quantities of $3 \mathrm{~g} \mathrm{cutting}^{-1}$, one month after the transplant into the bags. Additionally, a fertilization with $0.9 \mathrm{~kg} \mathrm{~m}^{-3}$ of urea, $0.4 \mathrm{~kg} \mathrm{~m}^{-3}$ of ammonium sulfate and $0.3 \mathrm{~kg} \mathrm{~m}^{-3}$ of triple superphosphate + simple superphosphate was performed in all the cuttings.

Throughout 330 days following the transplant, approximately every two weeks, the stem diameter (10 $\mathrm{cm}$ above the substrate line) was measured with a digital caliper. The average relative humidity and temperature in this period were respectively $84.7 \%$ and $15.1{ }^{\circ} \mathrm{C}$, for the fall/winter, and $73.9 \%$ and $24{ }^{\circ} \mathrm{C}$, for the spring/summer. Repeated analysis of variance and regression were performed to measure the stem diameter using the SPSS $18.0^{\circledR}$ software.

Finally, 330 days after transplantation, the percentage of survival, grafting suitability (stem diameter greater than $6 \mathrm{~mm}, 10 \mathrm{~cm}$ above the substrate line) and cutting shoot height (from the stem base to the terminal bud) were evaluated. These variables underwent an analysis of variance and their means were compared using the t-Student test $(p<0.05)$, with the SPSS $18.0^{\circledR}$ software.

\section{RESULTS AND DISCUSSION}

The interaction of cuttings collection season $\mathrm{x}$ IBA concentration $(\mathrm{p}<0.001)$ and cuttings collection season $x$ genotype $(p<0.05)$ were significant for the 
rooting variable (Table 1). The rest of the variables did not have significant interactions.

The rooting percentage was significantly lower for cuttings collected during the fall season, when compared to the ones collected at the end of the spring (Table 1), which presented rooting of $99 \%$, regardless of the IBA concentrations. The cuttings collected in the fall showed a very low rooting index in the absence of auxin $(3.5 \%)$, increasing proportionally with IBA concentrations, reaching $23.3 \%$ on the highest concentration.

The rooting percentage was similar between the two hybrids (over $99 \%$ ), in the cuttings collected at the end of the spring (Table 1). However, when the cutting was collected during the fall, the rooting index dropped, mainly on the hybrid $\mathrm{H} 49$, which reached $10.2 \%$. These results resemble the ones found by Andrade \& Martins (2003), in which the rooting was influenced by the species and the collection season, being higher during the spring $(56.1 \%)$ than during the fall (32.6\%), for four citrus rootstocks. Nevertheless, Oliveira et al. (2014) found absent rooting or a very low one $(<10 \%)$, for mandarin and its hybrids, in 15 rootstock genotypes treated with $4,000 \mathrm{mg} \mathrm{L}^{-1}$ and $6,000 \mathrm{mg} \mathrm{L}^{-1}$ of IBA, respectively. Similarly, roots were not observed in the rootstocks of Trifoliata [Poncirus trifoliata (L.) Raf.], 'Carrizo' citrange [C. sinensis (L.) Osb. x P. trifoliata], 'Cleopatra' mandarin (C. reshni Tan.) and '1452' citrumelo (C. paradisi $\mathrm{x} P$. trifoliata) collected during the spring, either in the control $\left(0 \mathrm{mg} \mathrm{L}^{-1}\right)$ or with $4,000 \mathrm{mg} \mathrm{L}^{-1}$ of IBA treatments (Uzun \& Seday 2011). In this study, the good performance of the hybrids in the spring season, regarding cuttings propagation, indicates the influence of both the genotype and

Table 1. Percentage of rooting of the hybrids H49 and H77, according to the indolebutyric acid (AIB) concentration and cuttings collection season.

\begin{tabular}{lcc}
\hline \multirow{2}{*}{$\begin{array}{c}\text { AIB concentration } \\
\left(\mathrm{mg} \mathrm{L}^{-1}\right)\end{array}$} & \multicolumn{2}{c}{ Cuttings collection season } \\
\cline { 2 - 3 } & \multicolumn{1}{c}{ Fall } & \multicolumn{1}{c}{ Spring } \\
\hline Absence $(0)$ & $3.5 \mathrm{Bb}$ & $99.0 \mathrm{Aa}$ \\
Medium $(1,500)$ & $15.9 \mathrm{Ab}$ & $100.0 \mathrm{Aa}$ \\
High $(3,000)$ & $23.3 \mathrm{Ab}$ & $100.0 \mathrm{Aa}$ \\
\hline \multicolumn{1}{c}{ Hybrid } & \\
\hline H49 & $10.2 \mathrm{Bb}$ & $99.3 \mathrm{Aa}$ \\
H77 & $18.3 \mathrm{Ab}$ & $100.0 \mathrm{Aa}$ \\
\hline CV $(\%)$ & 47.9 & 0.4 \\
\hline
\end{tabular}

Means with the same capital letter, in the column, and the same lower case letter, in the row, do not differ significantly $(\mathrm{p}<0.05)$ from each other, according to t-tests with Bonferroni adjustment. the management of the mother plant or the rooting environment.

The hybrid $\mathrm{H} 77$ presented higher means in the number of adventitious roots per cutting (3.5) and less cutting sprouting percentage (Table 2). This behavior suggests that, until the evaluated phase, the hybrid $\mathrm{H} 77$ turned its metabolism mainly to roots growth, whereas the $\mathrm{H} 49$ prioritized shoots growth. The number of roots in the rooting of citrus cuttings is heavily influenced by the cultivar or genotype (Andrade \& Martins 2003, Uzun \& Seday 2011, Oliveira et al. 2014). The quality of the root system indirectly measured by the number of roots per cutting is important to indicate a higher initial growth potential, when the cutting is transplanted in the field (Santos et al. 2010).

Concerning sprouting, the cuttings collected by the end of spring were superior $(72.4 \%)$, when compared to those collected during the fall (37.4\%) (Table 2). A similar response was evidenced on the number of roots (Table 2).

The best response obtained in the sprouting and rooting of the cuttings collected by the end of the spring may be a consequence of the highest quantity of carbohydrates in the stems of the cuttings (Goldschmidt 1999, Felzener et al. 2007) (Table 3). Another factor that may explain the best performance of the spring cuttings is the better temperature of the intermittent mist chamber at the end of the spring and

Table 2. Percentage of sprouting (SC) and number of roots (NR) for cuttings of the hybrids $\mathrm{H} 49$ and $\mathrm{H} 77$ subjected to different concentrations of indolebutyric acid (IBA) and collected during the fall and spring seasons.

\begin{tabular}{lcc}
\hline \multicolumn{1}{c}{ Simple effect } & \multicolumn{2}{c}{ Variable analyzed } \\
\hline \multicolumn{1}{c}{ Hybrid } & SC $(\%)$ & NR \\
\hline H49 & $61.5 \mathrm{a}$ & $2.7 \mathrm{~b}$ \\
H77 & $47.9 \mathrm{~b}$ & $3.5 \mathrm{a}$ \\
\hline Mean & 54.7 & 3.1 \\
\hline Collection season & & \\
\hline Fall & $37.0 \mathrm{~b}$ & $1.5 \mathrm{~b}$ \\
End of spring & $72.4 \mathrm{a}$ & $4.7 \mathrm{a}$ \\
\hline Mean & 54.7 & 3.1 \\
\hline IBA $\left(\mathrm{mg} \mathrm{L}^{-1}\right)$ & & \\
\hline 0 & $47.7^{\mathrm{ns}}$ & $2.2 \mathrm{~b}$ \\
1,500 & $59.7^{\mathrm{ns}}$ & $3.4 \mathrm{a}$ \\
3,000 & $56.8^{\mathrm{ns}}$ & $3.7 \mathrm{a}$ \\
\hline Mean & 54.6 & 3.1 \\
\hline CV $(\%)$ & 20.6 & 32.5 \\
\hline
\end{tabular}

Means with the same lower case letter, in the column, do not differ significantly $(\mathrm{p}<0.05)$ from each other, according to t-tests with Bonferroni adjustment. ${ }^{\text {ns }}$ non-significant. 
summer seasons (around $26.8^{\circ} \mathrm{C}$ ). During the fall and winter seasons, the average temperature of the intermittent mist chamber was $15.3^{\circ} \mathrm{C}$.

The IBA application to the roots of the cuttings did not influence the sprouting percentage (Table 2). However, it increased the number of roots per cutting significantly, going from 2.2 roots per cutting under auxin absence to 3.4 roots under the concentration of $1,500 \mathrm{mg} \mathrm{L}^{-1}$ and 3.7 roots under the highest concentration evaluated $\left(3,000 \mathrm{mg} \mathrm{L}^{-1}\right)$ (Table 2$)$.

The reserve contents did not differ between the hybrids (H49: $49.9 \%$; H77: $50.9 \%$ ) for the leaves, but they were higher in the hybrid H49, during the spring collection season (H49: $26.7 \%$; H77: $21.4 \%$ ), at the beginning of the experiment. In turn, the collection season influenced the tissue reserves, which were higher in the stems $(21.0-24.0 \%)$ and lower in the leaves (54.9-45.9\%), during the collection at the end of the spring, when compared to the fall season (Table 3 ).

There was not a significant effect of IBA on the contents of reserve substances in the stems and leaves of cuttings (Table 4). Meanwhile, the stems of the cuttings collected during the spring presented a significantly lower accumulation $(22.1 \%)$, if compared to the fall $(26.1 \%)$ (Table 4$)$. This behavior is explained by the higher rooting of the cuttings collected during the spring, which generated a lower translocation of the initial reserves from the leaves to the stems (Felzener et al. 2007).

During the fall collection season, there was a more intense translocation of reserves toward the stems from the IBA application to help in the process

Table 3. Relative contents of total reserves in the leaves and stems of cuttings of two hybrids (H49 and H77), during the fall (04/14/2013) and at the end of the spring (11/17/2013). Samples were obtained before going into the mist chamber for rooting.

\begin{tabular}{|c|c|c|c|c|}
\hline \multicolumn{5}{|c|}{ Total reserves content $(\%)$} \\
\hline & Collection season & $\mathrm{H} 49$ & $\mathrm{H} 77$ & Mean \\
\hline \multirow{3}{*}{ Leaf } & Fall & $54.5^{\mathrm{ns}}$ & $55.3^{\mathrm{ns}}$ & $54.9 \mathrm{~A}$ \\
\hline & End of spring & $45.3^{\mathrm{ns}}$ & $46.5^{\text {ns }}$ & $45.9 \mathrm{~B}$ \\
\hline & Mean & $49.9^{\text {ns }}$ & $50.9^{\text {ns }}$ & \\
\hline \multirow{3}{*}{ Stem } & Fall & $19.3^{\mathrm{ns}}$ & $22.7^{\mathrm{ns}}$ & $21.0 \mathrm{~B}$ \\
\hline & End of spring & $26.7 \mathrm{a}$ & $21.4 \mathrm{~b}$ & $24.0 \mathrm{~A}$ \\
\hline & Mean & $23.0^{\mathrm{ns}}$ & $22.0^{\mathrm{ns}}$ & \\
\hline \multicolumn{2}{|c|}{ CV $(\%)$} & 38.6 & 40.5 & 39.4 \\
\hline
\end{tabular}

Means with the same capital letter, in the column, and the same lower case letter, in the row, do not differ significantly $(\mathrm{p}<0.05)$ from each other, according to t-tests with Bonferroni adjustment. ${ }^{\text {ns }}$ non-significant. of root emission, during the rooting process in the mist chamber. As a result, a lower content of reserves in the leaves $(47.4 \%)$ and a higher one in the stems (26.1\%) were observed (Table 4), when compared to the reserves data obtained right after the cuttings were collected $(54.9 \%$ and $21.0 \%$, respectively) (Table 3).

In Citrus spp., the root system is normally the main organ of carbohydrate storage, but high concentrations may also be found in the leaves (Goldschmidt \& Golomb 1982), confirming the results found in this study.

The reserves accumulation in citrus under subtropical conditions occurs during the fall/winter, and the mobilization at the same level happens during the spring (Goldschmidt 1999). This was proved in Spain, with the 'Salustian' sweet orange (C. sinensis L.), in which the total carbohydrate accumulation in the leaves started in September and November (fall), and fully saturated in December (winter), decreasing later at the beginning of the bud sprouting, until fruit ripening (Monerri et al. 2011). This was confirmed in the present study.

In the second phase of the experiment, the vegetative growth of rooted cuttings was evaluated in $4.5 \mathrm{~L}$ plastic bags. The hybrids presented a good performance and survival $(>80 \%)$, reaching a higher stem diameter for the hybrid H49 (6.4 mm), when compared to the $\mathrm{H} 77$ (5.6 mm), 330 days after the transplant (Table 5). At this point, more than $50 \%$ of the cuttings were optimal for grafting (diameter $>6 \mathrm{~mm}$ ), with the hybrid $\mathrm{H} 49$ performing better (Table 5). Pio et al. (2006) referred that

Table 4. Relative content of total reserves in the cuttings stems and leaves of two hybrids (H49 and H77), for the fall and spring seasons, after 90 to 130 days in the intermittent mist chamber, treated with different IBA concentrations.

\begin{tabular}{|c|c|c|c|c|c|}
\hline \multicolumn{6}{|c|}{ Total reserves content $(\%)$} \\
\hline & Collection season & 0 & 1,500 & 3,000 & Mean \\
\hline \multirow{3}{*}{ Leaf } & Fall & $47.5^{\mathrm{ns}}$ & $47.7^{\mathrm{ns}}$ & $47.1^{\mathrm{ns}}$ & $47.4^{\mathrm{ns}}$ \\
\hline & End of spring & $46.1^{\mathrm{ns}}$ & $45.1^{\mathrm{ns}}$ & $49.6^{\mathrm{ns}}$ & $46.9^{\text {ns }}$ \\
\hline & Mean & $46.4^{\mathrm{ns}}$ & $46.4^{\mathrm{ns}}$ & $48.3^{\mathrm{ns}}$ & \\
\hline \multirow{3}{*}{ Stem } & Fall & $25.5^{\mathrm{ns}}$ & $25.1^{\mathrm{ns}}$ & $27.7^{\mathrm{ns}}$ & $26.1 \mathrm{a}$ \\
\hline & End of spring & $22.6^{\mathrm{ns}}$ & $20.8^{\mathrm{ns}}$ & $22.9^{\text {ns }}$ & $22.1 \mathrm{~b}$ \\
\hline & Mean & $24.1^{\mathrm{ns}}$ & $22.9^{\mathrm{ns}}$ & $22.2^{\mathrm{ns}}$ & \\
\hline $\mathrm{CV}(\%)$ & & 38.1 & 34.2 & 31.7 & 30.4 \\
\hline
\end{tabular}

The IBA treatment did not affect the total reserves of plants ( ${ }^{\text {(ns }}$ non-significant). The only significance was observed between the season (fall $v s$. end of the spring) for the reserves on stems, according to t-tests with Bonferroni adjustment. 
$22.5 \%$ of the somatic hybrid 'Rangpur' lime $\mathrm{x}$ 'Sunki' mandarin cuttings were optimal for grafting (diameter $>6.5 \mathrm{~mm}$ ) at 210 days after the transplant into bags. They stated that even though the cuttings propagation has a comparatively longer period than rootstocks produced by seeds, this method is appropriate, given the good budtake percentages, compatibility and vigor. Comparatively, only six months after the transplant into plastic bags, the cuttings from the 'Sunki Tropical' mandarin had values $(5.9 \mathrm{~mm}, 10 \mathrm{~cm}$ above the stem collar) close to those required for grafting in the Bahia State, Brazil (Oliveira et al. 2014).

According to the analysis of variance of the stem diameter growth, there was an interaction

Table 5. Cuttings survival percentage (VC), shoot height (HC), stem diameter $10 \mathrm{~cm}$ above the substrate (SDC) and cuttings optimal percentage for grafting (GC) of the hybrids $\mathrm{H} 49$ and $\mathrm{H} 77,330$ days after the transplant into 4.5 L plastic bags.

\begin{tabular}{lcccc}
\hline \multicolumn{1}{c}{ Hybrid } & VC $(\%)$ & HC $(\mathrm{cm})$ & SDC $(\mathrm{mm})$ & GC $(\%)$ \\
\hline H49 & $83.7^{\text {ns }}$ & $71.1 \mathrm{a}$ & $6.4 \mathrm{a}$ & $58.8 \mathrm{a}$ \\
H77 & $79.5^{\text {ns }}$ & $59.2 \mathrm{~b}$ & $5.6 \mathrm{~b}$ & $43.8 \mathrm{~b}$ \\
\hline Mean & 81.6 & 65.4 & 6.1 & 51.3 \\
\hline CV $(\%)$ & 3.6 & 22.2 & 14.1 & 20.8 \\
\hline
\end{tabular}

Means followed by different letters in the column belong to different groups ( $p>0.05$ ), according to t-tests with Bonferroni adjustment. ${ }^{n s}$ non-significant.

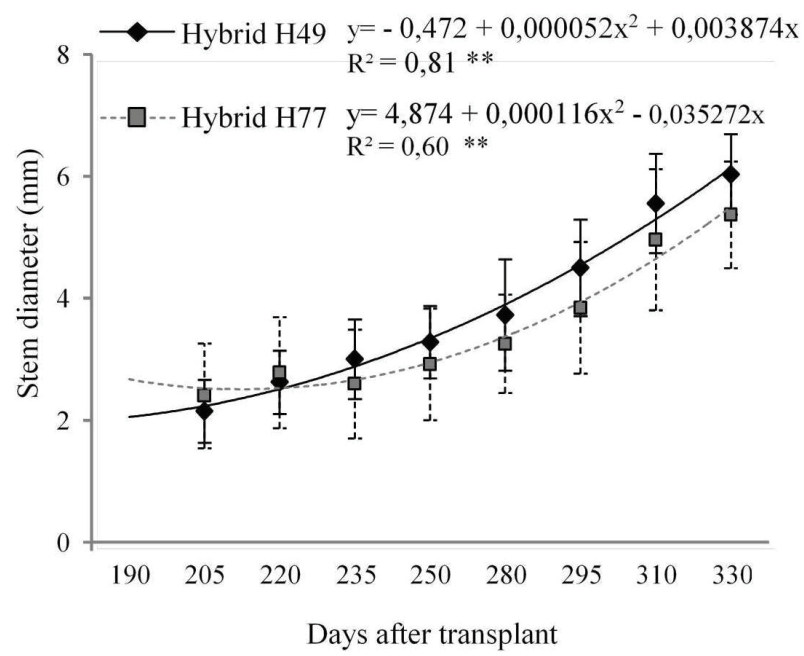

Figure 1. Evolution of the stem diameter $(10 \mathrm{~cm}$ above the substrate line) of the hybrids H49 and H77 obtained by cuttings, through 330 days of cultivation in $4.5 \mathrm{~L}$ plastic bags kept in a greenhouse. * Significant at $1 \%$. Each point represents the means $(n=18)$, and bars represent the standard deviation. effect of time $x$ hybrid $(p<0.05)$. This variable slowly increased over the first eight months after transplant, a process that was accelerated at the end of the period evaluated (Figure 1). This growth coincided with the end of the spring and the beginning of the summer, which have higher average temperatures $\left(25-30{ }^{\circ} \mathrm{C}\right)$, optimal for the citrus development (Machado et al. 2005) due to the accelerated metabolic activity.

The increase in the diameter of both hybrids presented a quadratic response (Figure 1), in which H49 - that started with a lower diameter - showed superior values than the ones observed for the hybrid H77, 220 days after the transplant. At the end of the period, the shoot height was higher on the hybrid H49 (Table 5). Differences in vigor between the citrus rootstocks are expected (Fochesato et al. 2007). In this study, the difference in vigor between the hybrids $\mathrm{H} 49$ and $\mathrm{H} 77$ is probably due to genotypic differences between them.

\section{CONCLUSIONS}

1. The propagation of the hybrids H49 and H77 by cuttings is viable, especially at the end of the spring, which is the most appropriate season for the collection of cuttings in the South of Brazil.

2. Cuttings of the hybrids H49 and H77 collected by the end of the spring do not need exogenous auxin supplements for rooting.

3. The hybrid H49 has better aptitude for cuttings propagation and more vigor in its vegetative growth than the $\mathrm{H} 77$.

\section{ACKNOWLEDGMENTS}

The authors are grateful to the Conselho Nacional de Desenvolvimento Científico e Tecnológico (CNPq) and Fundação de Amparo à Pesquisa do Estado do Rio Grande do Sul (FAPERGS), for funding this research.

\section{REFERENCES}

ANDRADE, R. A.; MARTINS, A. B. G. Propagação vegetativa de porta-enxertos para citros. Revista Brasileira de Fruticultura, v. 25, n. 1, p. 134-136, 2003.

BASSANEZI, R. B. et al. Effect of citrus sudden death on yield and quality of sweet orange cultivars in Brazil. Plant Disease, v. 91, n. 11, p. 1407-1412, 2007. 
FELZENER, L. T. et al. Efeitos de reguladores vegetais no enraizamento de estacas caulinares de Poncirus trifoliata var. monstrosa (T. Ito). Revista Brasileira de Fruticultura, v. 29, n. 2, p. 399-402, 2007.

FOCHESATO, M. L. et al. Crescimento vegetativo de porta-enxerto de citros produzidos em substratos comerciais. Ciência Rural, v. 37, n. 4, p. 970-975, 2007.

GOLDSCHMIDT, E. E. Carbohydrate supply as a critical factor for citrus development and productivity. HortScience, v. 34, n. 6, p. 1020-1024, 1999.

GOLDSCHMIDT, E. E.; GOLOMB, A. The carbohydrate balance of alternate-bearing citrus trees and the significance of reserves for flowering and fruiting. Journal of the American Society of Horticultural Science, v. 107, n. 2, p. 206-208, 1982.

KOLLER, O. C. (Coord.). Citricultura, cultura de tangerineiras: tecnologia de produção, pós-colheita e industrialização. Porto Alegre: Rieguel, 2009.

MACHADO, E. C. et al. Respostas da fotossíntese de três espécies de citros a fatores ambientais. Pesquisa Agropecuária Brasileira, v. 40, n. 12, p. 1161-1178, 2005.

MONERRI, C. et al. Relation of carbohydrate reserves with the forthcoming crop, flower formation and photosynthetic rate, in the alternate bearing 'Salustian' sweet orange (Citrus sinensis L.). Scientia Horticulturae, v. 129, n. 1, p. 71-78, 2011.

OLIVEIRA, E. M. et al. Efeito do ácido indolbutírico no enraizamento e no crescimento de quinze porta-enxertos de citros propagados por estaquia. Citrus Research \& Technology, v. 35, n. 1, p. 35-43, 2014.

PIO, P. et al. Propagation of citrus somatic hybrids with potential for utilization as rootstocks. Fruits, v. 61, n. 1, p. 1-7, 2006.

POMPEU JÚNIOR, J.; BLUMER, S. Citrandarins e outros híbridos de trifoliata como porta-enxerto para laranjeira
Valência. Citrus Research \& Technology, v. 32, n. 3, p. 133-138, 2011.

PRIESTLEY, G. A new method for the estimation of the resources of apple trees. Journal of the Science of Food and Agriculture, v. 16, n. 12, p. 717-721, 1965.

RAO, M. N. et al. Characterization of zygotic and nucellar seedlings from sour orange-like citrus rootstock candidates using RAPD and EST-SSR markers. Tree Genetics \& Genomes, v. 4, n. 1, p. 113-124, 2008.

SANTOS, C. M. et al. Substratos e regulador vegetal no enraizamento de estacas de pitaya. Revista Ciência Agronômica, v. 41, n. 4, p. 625-629, 2010.

SANTOS, C. Q. et al. Tamanho ótimo de amostras de frutos e de sementes para determinação da poliembrionia em citros. Revista Brasileira de Fruticultura, v. 37, n. 1, p. 172-178, 2015.

SIVIERO, A.; CRISTOFANI, M.; MACHADO, M. A. QTL mapping associated with rooting stem cuttings from Citrus sunki vs. Poncirus trifoliata hybrids. Crop Breeding and Applied Biotechnology, v. 3, n. 1, p. 83-88, 2003.

SOUZA, P. V. D.; SCHÄFER, G. Produção de mudas de laranjeiras. In: KOLLER, O. C. (Org.). Citricultura: laranja: tecnologia de produção, pós-colheita, industrialização e comercialização. Porto Alegre: Cinco Continentes, 2006. p. 55-87.

UZUN, A.; SEDAY, U. Effects of different IBA doses on rooting of hardwood cuttings of some citrus rootstocks. Ercylyes University Journal of the Institute of Science and Technology, v. 27, n. 2, p. 212-216, 2011.

WEILER, R. L. et al. Teste de paternidade e avaliações agronômicas de possíveis híbridos de tangerineira 'Sunki'. Scientia Agraria, v. 10, n. 6, p. 429-435, 2009. 